\title{
Evaluation of potential erodibility of basin wetland using soil particles distribution
}

\author{
O. E. Essien \\ Department of Agricultural and Food Engineering University of Uyo, Uyo, P. O. Box 4309, Uniuyo Post Office, \\ Uyo, Nigeria. Postal Code: 520003
}

\begin{abstract}
The objective of this study was to predict soil erodibility using soil properties of upper and lower tributary river (Enyong Creek and Ikpa river) basins wetland, comprising different soil groups or series. Mathematical formulation used for the nomograph of Wischmeier et al was used for the evaluation. Investigated soil properties included soil organic matter (SOM); granulometry of silt and clay; soil structure and permeability. The predicted K-factors, hence soil erodibility potentials, were high and significantly different $(p<.05)$ from each catchment soil, and ranged between 0.0073 and 0.0827 for Ikpa River wetland, and between 0.0827 and 0.121 for Enyong Creek wetland. Percentage SOM was significantly different $(P<0.01)$ between the wetlands, with Ikpa river wetland registering higher values. Percentage clay in Ikpa was generally higher than its values in Enyong Creek; other properties were not significantly different. Significant correlation was observed between silt percentage and erodibility factor. Further investigation is required between $K$-factor and influence of saturated hydraulic conductivity. However, the study provided baseline information on wetland erodibility for the reduction of soil susceptibility to erosion when considering any appropriate wetland development projects.
\end{abstract}

Keywords: Soil erodibility, K-factor, river basin development, granulometry, wetland erosion.

\section{Introduction}

Soil erosion is the vagaries from environmental agents (rainfall, runoff, streams, and wind) solely or coupled with anthropogenic factors. While nature builds the land, its agencies along with human and animal factors, destroy the land surface by erosion and, in many cases, destroy down the soil sublayer by gully and tunnel erosion. The need for environmental sustainability of land for agricultural resource productivity informed the formulation of the program of soil conservation such as composed by Revised Universal Soil Loss Equation, RUSLE [1,2] in which conservation practices evaluated the K- factor, called erodibility factor, to assess the potential of soil being vulnerable to the vagaries of erosion so as to plan against its incipience or progress. Soil erosion, generally is a three-step process of soil particles detachment, particles transportation or displacement and finally deposition ata different or new location [3]. Soil itself is a material with greater or lesser degree of cohesion and therefore is vulnerable. The susceptibility of each soil surface to the vagaries of erosion defines soil's erodibility, which is soil's intrinsic property defined by the soil's resistance to two impactful energy sources: the impact of raindrops on soil surface, and the shearing action of surface runoff over soil surface as sheet erosion or between clods in grooves or rills (as in rill erosion) etc. [1,4].

Soil physical properties, namely, particle size distribution (soil texture), structure, organic matter and permeability govern erodibility [1,2,3, and 5]. Texture is the mix proportion of sand, silt and clay. Erodibility is low for clay-rich soils with a low-shrink-swell capacity because these clay particles aggregates resist detachment and transport, while sandy soils with large amount of fine, medium, or coarse sand particles ( 0.10 $2.0 \mathrm{~mm}$ diameter) are found to have low erodibility $[6,3]$. Structure is the aggregation of individual soil particles (sand, silt, clay) into larger aggregates of identifiable shape, and good aggregation enables the soil to resist the detachment forces of water and rainfall impact by holding particles together. Soil organic matter (SOM), being highly decomposed organic material in soils, is highly available in topsoil and act as a glue to bind soil particles together into stickier aggregates, thereby offering resistance to erosion if its SOM is high [3].Permeability is the measure of rate at which water percolates through the soil under a head of water in soil and is a function of soil texture, structure and bulk density, hence a function of soil particles. For instance, sandy soils with large amounts of fine, medium, or coarse sand particles $(0.10-2.0 \mathrm{~mm})$ also have low erodibility [3, 7]. Therefore, in general, all these factors depend on soil particles size (sand, silt, clay) and SOM; hence edibility can be defined by the soil particle size distribution $[1,2,3,8]$.

Researchers have used different methods to relate soil erosion potential (soil erodibility) to topsoil condition or soil particles distribution. Example is the SCS county soil-survey report [9]. Nomographs have been formulated but were limited to where mineral disturbance at the site was anticipated as site analysis was unavailable $[8,9]$. Bouyoucos related erodibility to the percentages of sand, silt and clay $[1,8]$. However, the method of K-factor (soil erodibility factor) as evaluated by [9], which is a mathematical representation of $[9,10]$ 
is preferred as it integrates many factors of the soil ecosystem, thereby simulating the real soil ecosystem in the erosion process.

Particle size distribution is very important in soil conservation, engineering, and management as such inherent properties of the soil can influence its erodibility, and hence could be managed to reduce soil erosion potential in a geographic extent [3]. However, soil particles cannot be known off-hand as they are soil properties at specific field locations [4]. Hence, they must be investigated before applying the mathematical tools to the established particles. This is necessary for Enyong Creek and Ikpa river watersheds which are largely in undisturbed state, with annual rainfall as high as $2000-3000 \mathrm{~mm}$ and daily or N-day rainfall of $200-300 \mathrm{~mm}$ [12] which offer great potentials for soil erosion.

Therefore, the objectives of the study were to evaluate soil properties in the soil groups of the study area landforms and apply them in a mathematical formulation to determine K-factor and evaluate the soil erosion potential (or risk) on the catchment wetland.

\subsection{Study Area}

\section{Materials And Methods}

The study area covered the wetlands of Itu/Igwu and Enyong subcatchments in northern Akwa Ibom State. The field survey was carried out in collaboration with Akwa Ibom Agricultural Development Project in 1999 , and had the grid of $1000 \mathrm{~m} \times 1000 \mathrm{~m}$ for XYZ and $100 \mathrm{~m} \times 100 \mathrm{~m}$ for Z information respectively. Field survey $(1: 20,000$ scale) showed the swamp or wetland profile to be generally flat with slopes ranging from 0.5 $3 \%$ except at the gentle undulation of river terraces which formed small islands of dry land having elevation from 5-45m above mean sea level [12].

\subsection{Site description}

The area covered the whole of Enyong Creek and Ikpa river catchments which drainage river (Enyong Creek and Ikpa) are upper and lower tributaries to Cross River, hence making their respective catchments the upper and lower tributary catchments in Cross River basin. Enyong Creek and Ikpa river catchmens have area coverage of $1400 \mathrm{~km}^{2}$, and $450 \mathrm{~km}^{2}$ respectively. Soil samples were taken by arguring from 50 sites and examined by 3 profile pits in Enyong and Ikpa basins (the upper and lower tributary swamps to Cross River).

Soil properties were investigated by arguring to $100 \mathrm{~cm}$ except at sites where soil proved impenetrable at shallow depth. Texture was examined by land-held lenses. Composite topsoil samples consisting of 5 subsamples were taken from $0-10$ and $10-20 \mathrm{~cm}$ depths. Soil samples for laboratory analysis were taken with the auger from all soil horizons distinguished in the profile pits. Where necessary, soil samples below the water table were also taken with the auger. The samples were properly labeled in plastic bags and conveyed to the laboratory where they were air-dried at room temperature; after which the dried samples were ground in mortars to pass through a 2-mm sieve, prior to physical (and chemical) analysis. For the determination of organic matter, total N, P, K and micro nutrients, the samples were ground again to pass through 100-mesh sieve.

The particle size analysis of the soil samples used the hydrometer method with calgon or hexametaphosphate solution as the dispersing agent $[13,14,15]$. The sand fraction was separated into coarse and fine by sieving. $\mathrm{pH}$ used a $\mathrm{pH}$ meter in water and $\mathrm{KCl}$ solution in 1:2 soil-to-suspension ratio. Organic carbon content was obtained by the dichromate-oxidation method of [16].

\subsection{Soil parameters}

Textural class of the soil was identified using USDA texture tangible. For soil structure, the exposed soil surface in the profile pit was carefully studied with the aid of a hand lens. The arrangement of the soil aggregates was examined and described using Ahn's (1971) specification as very fine granular, fine granular, coarse granular, and blocky (or platty or massive) and assigned codes 1,2,3,4 respectively according to $[10,17]$. For permeability, using the previously cut transects and grid spacing of $1000 \mathrm{~m}$ intervals along the transects, auger hole method was used to measure the soil saturated hydraulic conductivity at $0-25 \mathrm{~cm}$ profile depth at locations within the relevant major and minor soil series on the wetland and upland areas. Infiltration rate and hydraulic conductivity measuring location was spatially distributed about $200 \mathrm{~m}$ along the lateral pre-cut transects and $1000 \mathrm{~m}$ along the longitudinal pre-cut transects. The auger-hole method followed the approach described in [7].

\subsection{Statistical analysis}

Data were statistically analyzed using the SPSS system version 17 Word. 2.5 Mathematical equation of soil factor, $\mathrm{K}_{\text {fact }}[9,10,11]$.

$K_{\text {fact }}=1.292\left[2.1 \times 10^{-6} \int_{p}^{1.14} \times\left(12-P_{0 m}\right)+0.0325\left(S_{\text {stru }}-2\right)+0.025\left(f_{\text {perm }}-3\right)\right]$

where: 
$f_{p}=\mathrm{P}_{\text {silt }}\left(100-\mathrm{P}_{\text {clay }}\right)$

$f_{p}=$ the particles size parameter

$P_{0 m}=$ is the percent of organic matter

$P_{\text {struct }}$ is the soil structure index

$f_{\text {perm }}$ is the profile permeability class factor

$P_{\text {silt }}$ is the percent silt, and

$P_{\text {clay }}$ is the percent clay.

And, where 1.292 converts English unit used in [9,10] to metric unit [11]. $S_{\text {struc }}$ is equal to: 1 for very fine granular soil; 2 for fine granular soil; 3 for medium or coarse granular soil; 4 is for blocky, platy or massive soil; where $f_{\text {perm }}$ is equal to: 1 for very slow infiltration; 2 for slow infiltration; 3 for slow to moderate infiltration; 4 for moderate infiltration; 5 for moderate to rapid infiltration; 6 for rapid infiltration [11].

\section{Results}

3.1Specific characteristics of the site of the representative soil series in the wetland are summarized in Table 1. Soil series encoded EN 31, 33, 51, 52, 53 are shown with their categories of soil type, soil structure and permeability and examples.

\subsection{Predicting Erodibility Factor, K-factor}

The values of $\mathrm{P}_{\mathrm{om}}, \mathrm{S}_{\text {struc }}, \mathrm{f}_{\text {perm }}, \mathrm{P}_{\text {silt }}$ and $\mathrm{P}_{\text {clay }}$ in equation (1) were evaluated based on the site characteristics. The data on $\mathrm{P}_{\text {silt }}, \mathrm{P}_{\text {clay }}$ and $\mathrm{P}_{\text {om }}$ were retrieved from Akwa Ibom Agricultural Development Project (AKADEP) data bank for Northern Akwa Ibom Swamps Resources study [12].

Using the values of $P_{\text {silt }}, P_{\text {clay }}, P_{\text {om }}, P_{\text {struc }}, f_{\text {perm }}$ and $f_{p}$ into (1), the erodibility factor (K-factor) was computed for each set of data on the different soil series. The results of computed K-factor based on soil properties of Ikpa river catchments soils are shown in Table 2, while those on Enyong Creek basin wetland soils are summarized in Table 3 .

$K_{\text {fact }}$ Was interpreted into erodibility class [18] as:

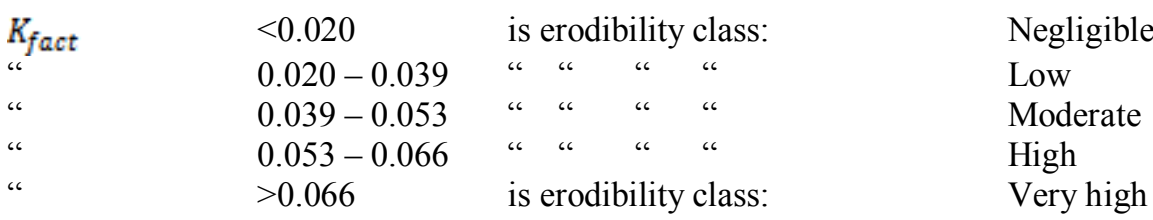

TABLE 1: Site description and characteristics of soil series sites in Enyong Creek and Ikpa River

\begin{tabular}{|c|c|c|c|c|c|}
\hline Soil series & $\begin{array}{l}\text { Texture/drainage } \\
\text { class }\end{array}$ & $\begin{array}{l}\text { Soil structure } \\
\left(\mathrm{S}_{\text {stonet }}\right)\end{array}$ & Permeability & Vegetation & $\begin{array}{l}\text { Swamps/ } \\
\text { Examples of }\end{array}$ \\
\hline EN 31 & $\begin{array}{l}\text { The main } \\
\text { imperfectly } \\
\text { drained fine } \\
\text { texture soil }\end{array}$ & $\begin{array}{l}\text { Profile: } 15 \mathrm{~m} \text {, } \\
\text { sandy clay, } 10 \mathrm{~cm} \text {, } \\
\text { strongly developed } \\
\text { medium blocky } \\
\text { subangular } \\
\text { structure }\left(\mathrm{S}_{\mathrm{struc}}=4\right)\end{array}$ & $\begin{array}{l}\text { Moderate } \geq \\
20 \mathrm{~cm} ; \text { rapid }< \\
20 \mathrm{~cm} \mathrm{~K}_{\text {at }} 3.1 / \text { day }\end{array}$ & $\begin{array}{l}\text { Vegetative } \\
\text { cover: mainly } \\
\text { dry land crops + } \\
\text { associated } \\
\text { fallow, or cocoa } \\
\text { but some area } \\
\text { are under forest. }\end{array}$ & $\begin{array}{l}\text { soil series } \\
\text { Nkari(A) west, } \\
\text { NK } 10 / 1200 \\
\text { Itu South (B) } \\
\text { MB } 1 / 100 \\
\text { use west (J) } \\
\text { US 7B/400 }\end{array}$ \\
\hline EN 31 & $\begin{array}{l}\text { The main } \\
\text { imperfectly } \\
\text { drained fine } \\
\text { texture soil }\end{array}$ & & & & \\
\hline EN 33 & $\begin{array}{l}\text { Imperfectly } \\
\text { drained soils with } \\
\text { coarse over fine } \\
\text { texture profiles }\end{array}$ & $\begin{array}{l}\text { Profile } 10 \mathrm{~cm} \text { : } \\
\text { weakly developed } \\
\text { medium } \\
\text { subangular block } \\
\text { structure }\left(\mathrm{S}_{\mathrm{struc}}=4\right.\end{array}$ & & $\begin{array}{l}\text { Farm land/rice } \\
\text { field } \\
\text { (EkoiMbatfam) }\end{array}$ & $\begin{array}{l}\operatorname{Igwu}(\mathrm{E}) \\
2 \mathrm{~B} / 200\end{array}$ \\
\hline Dysticfluvisol & $\begin{array}{l}\text { Imperfectly } \\
\text { drained soils with } \\
\text { coarse over fine } \\
\text { texture profiles }\end{array}$ & & & & \\
\hline $\begin{array}{lr}\text { EN } & 51 \\
\text { Eutricgleyicfluvisol }\end{array}$ & Poor drained clay & $\begin{array}{l}\text { Weak medium } \\
\text { subangular blocky } \\
\text { structure }\left(\mathrm{S}_{\mathrm{struc}}=4\right)\end{array}$ & $\begin{array}{l}\text { Moderately rapid } \\
\text { at } \geq 20 \mathrm{~cm}(5)\end{array}$ & $\begin{array}{l}\text { Diverse } \\
\text { vegetation or } \\
\text { land use. Swamp } \\
\text { grassland, } \\
\text { swamp forest, } \\
\text { cocoa farm. }\end{array}$ & $\begin{array}{l}\text { Mbiabet (H) } \\
\text { MB 5/1000 }\end{array}$ \\
\hline
\end{tabular}


Evaluation of potential erodibility of basin wetland using soil particles distribution

\begin{tabular}{|c|c|c|c|c|c|}
\hline $\begin{array}{lr}\text { EN } & 51 \\
\text { Eutricglevicfluvisol }\end{array}$ & Poor drained & $\begin{array}{l}\text { Strong fine } \\
\text { subangular blocky } \\
\left(\mathrm{S}_{\text {struc }}=4\right)\end{array}$ & & & $\begin{array}{l}\text { Nkari (A) NK } \\
8 \mathrm{~A} / 00\end{array}$ \\
\hline $\begin{array}{lr}\text { EN } & 51 \\
\text { Eutricgleyicfluvisol }\end{array}$ & $\begin{array}{l}\text { Poor drained }(0- \\
2 \% \text { slope })\end{array}$ & $\begin{array}{l}\text { Moderately } \\
\text { medium } \\
\text { subangular block } \\
\left(\mathrm{S}_{\text {struc }}=4\right)\end{array}$ & & $\begin{array}{l}\text { Fellow Swamp } \\
\text { grass }\end{array}$ & $\begin{array}{l}\text { Use (J) US } \\
7 / 500\end{array}$ \\
\hline $\begin{array}{lr}\text { EN } & 51 \\
\text { Eutricgleyicfluvisol }\end{array}$ & $\begin{array}{l}\text { Very poor drained } \\
\text { (flood plain) }\end{array}$ & $\begin{array}{l}\text { Weak medium } \\
\text { subangular blocky } \\
\left(\mathrm{S}_{\text {struc }}=4\right)\end{array}$ & & $\begin{array}{l}\text { Swamp } \\
\text { grass/rice farm }\end{array}$ & $\begin{array}{l}\text { Mbiabet }(\mathrm{H}) \\
\text { MB 5A/200 }\end{array}$ \\
\hline $\begin{array}{lr}\text { EN } & 53 \\
\text { Eutricgleyicfluvisol }\end{array}$ & $\begin{array}{l}\text { Poor drain flat } 0 \text { - } \\
2 \%\end{array}$ & $\begin{array}{l}\text { Moderate } \\
\text { mediumsubangular } \\
\text { blocky (4) }\end{array}$ & Rapid 5 & $\begin{array}{l}\text { Main under } \\
\text { fallow rice field }\end{array}$ & $\begin{array}{l}\text { Use (1) us } \\
3 / 600\end{array}$ \\
\hline En 53 & $\begin{array}{l}\text { Poorly drained } \\
\text { flatland } 0-2 \%\end{array}$ & $\begin{array}{l}\text { Profile } 10 \mathrm{~cm} \text { : } \\
\text { weak, medium } \\
\text { subangularblecky } \\
\text { (4) }\end{array}$ & $\begin{array}{l}\text { Rapid@ } \leq 20 \mathrm{~cm} \\
\text { (form 6) at } \\
>20 \mathrm{~cm}, 5\end{array}$ & $\begin{array}{l}\text { Fallow/grassland } \\
\text { Iqwu swamp E }\end{array}$ & IG $3 \mathrm{~A} / 600$ \\
\hline $\begin{array}{lr}\text { EN } & 52 \\
\text { Eutrcgleyicfluvisol }\end{array}$ & $\begin{array}{l}\text { Very poorly } \\
\text { drained flood } \\
\text { plain }\end{array}$ & $\begin{array}{l}\text { Medium to coarse } \\
\text { grain }\end{array}$ & $\begin{array}{l}\text { Moderately rapid } \\
(5)>4 \mathrm{~cm}\end{array}$ & $\begin{array}{l}\text { Rice field } \\
\text { (Mbiabet rice } \\
\text { project swamp } \\
\text { H) }\end{array}$ & (H) $M R F / 1$ \\
\hline
\end{tabular}

Table 2. Input parameters for computation of $\mathrm{K}_{\text {fact }}$ and wetland erodibility class for soil series on Ikpa River

\begin{tabular}{|c|c|c|c|c|c|c|c|c|c|}
\hline Series & Depth & $\mathrm{pH}$ & $\begin{array}{l}\mathbf{P}_{\text {silt }} \\
\%\end{array}$ & $\begin{array}{l}\mathbf{P}_{\text {clav }} \\
\%\end{array}$ & $\mathbf{P}_{\mathrm{om}} \%$ & $\mathrm{~S}_{\text {struc }}$ & $\mathbf{f}_{\text {perm }}$ & $\mathbf{K}_{\text {fact }}$ & $\begin{array}{l}\text { Erodibility } \\
\text { class [18] }\end{array}$ \\
\hline \multicolumn{10}{|l|}{$\begin{array}{l}\text { EN 71 } \\
0-13 \mathrm{~cm}\end{array}$} \\
\hline MB $1 / 500$ & $0-10$ & 4.48 & 41.6 & 38.4 & 6.99 & 2 & 5 & 0.0569 & Low \\
\hline MB $1 / 1000$ & $0-10$ & 4.56 & 5.0 & 85.6 & 14.35 & 4 & 3 & 0.0651 & \\
\hline $\mathrm{MBl} / 2000$ & 0.10 & 4.55 & 10.2 & 22.6 & 6.34 & 3 & 5 & 0.0840 & High \\
\hline US $5 \mathbf{A} / \mathbf{8 0 0}$ & $0-10$ & 4.86 & 4.0 & 30.2 & 6.55 & 4 & 3 & 0.0409 & Low \\
\hline IK $1 / 400$ & $0-10$ & 4.97 & 41.4 & 29.4 & 8.67 & 2 & 3 & 0.0073 & Negligible \\
\hline IK $10 / 1000$ & $0-19$ & 4.40 & 14.8 & 34.8 & 0.69 & 3 & 5 & 0.0851 & High \\
\hline IK $11 / 400$ & $0-15$ & 4.59 & 19.4 & 34.4 & 10.59 & 3 & 5 & 0.0859 & 西 \\
\hline IK $11 / 800$ & $0-10$ & 4.83 & 14.6 & 57.4 & 13.62 & 4 & 3 & 0.0668 & Low \\
\hline IK $15 / 550$ & $0-10$ & 4.91 & 11.8 & 26.0 & 13.62 & 3 & 5 & 0.0848 & High \\
\hline Ik $20 / 2500$ & $0-18$ & 4.93 & 15.2 & 84.8 & 8.67 & 4 & 3 & 0.0656 & Low \\
\hline IK $3 / 600$ & $0-15$ & 4.42 & 8.0 & 40.8 & 7.12 & 3 & 5 & 0.0837 & High \\
\hline Ik $20 / 1500$ & $0-20$ & 4.92 & 28.9 & 71.1 & 10.84 & 3 & 2 & 0.0098 & Negligible \\
\hline Ik $21 / 2000$ & $0-10$ & 4.93 & 48.0 & 42.0 & 11.18 & 2 & 5 & 0.0576 & Low \\
\hline EN 72 & $0-15$ & 5.67 & 16.0 & 36.0 & 4.75 & 3 & 4 & 0.0603 & Low \\
\hline $\begin{array}{l}\text { EN 73 } \\
\text { Ik 3/800 }\end{array}$ & $0-10$ & 4.55 & 32.2 & 27.8 & 13.67 & 2 & 5 & 0.0560 & Low \\
\hline IK $9 / 100$ & $0-10$ & 5.21 & 24.6 & 34.4 & 13.64 & 2 & 5 & 0.05434 & Low \\
\hline IK $10 \mathrm{~A} / 400$ & $0-10$ & 4.53 & 0.80 & 4.8 & 15.26 & 3 & 5 & 0.0827 & High \\
\hline EN 61 & $0-5$ & 5.43 & 0.0 & 5.4 & 0.89 & 3 & 6 & 0.1080 & High \\
\hline IK 20/900 & $0-20$ & 4.78 & 38.7 & 31.3 & 11.51 & 2 & 5 & 0.0572 & Low \\
\hline IK $16 / 600$ & $0-10$ & 5.15 & 52.3 & 36.3 & 12.25 & 2 & 2 & 0.0090 & Negligible \\
\hline IK $01 / 400$ & $1-10$ & 4.80 & 28.4 & 15.2 & & & 3 & & \\
\hline IK $12 / 400$ & $0-10$ & 4.82 & 21.7 & 62.3 & 13.67 & 3 & 5 & 0.0847 & High \\
\hline IK $13 / 200$ & $0-10$ & 4.94 & 24.8 & 26.6 & 13.31 & 3 & 5 & 0.0874 & High \\
\hline IK $12 / 400$ & $0-10$ & 4.82 & 21.7 & 62.3 & 18.67 & 3 & 3 & 0.0347 & Low \\
\hline IK $12 / 200$ & $0-15$ & 5.53 & 52.4 & 26.6 & 11.23 & 3 & 3 & 0.0429 & Low \\
\hline US $6 / 1400$ & $0-15$ & 5.67 & 16.0 & 36.0 & 4.75 & 3 & 4 & 0.0603 & Low \\
\hline US $2 \mathrm{~B} / 900$ & $0-15$ & 5.03 & 14.0 & 26.2 & 3.70 & 3 & 4 & 0.0603 & Low \\
\hline NA $5 / 00$ & $0-15$ & 4.80 & 18.0 & 31.4 & 2.90 & 3 & 4 & 0.0609 & Low \\
\hline IK $2 / 100$ & $0-10$ & 4.88 & 42.2 & 27.8 & 6.65 & 3 & 5 & 0.0908 & High \\
\hline IK $2 / 200$ & $0-15$ & 4.62 & 46.8 & 8.4 & 11.82 & 3 & 5 & 0.0941 & High \\
\hline
\end{tabular}


Evaluation of potential erodibility of basin wetland using soil particles distribution

Table 3. Physio-chemical properties and erodibility factor and class for different soil groups in Enyong creek wetland

\begin{tabular}{|c|c|c|c|c|c|c|c|}
\hline Series and samples & $P_{\text {silt }}$ & $\mathbf{P}_{\mathrm{clar}}$ & $\mathbf{P}_{\mathrm{om}}$ & $S_{\text {struc }}$ & $f_{\text {perm }}$ & $\mathbf{K}_{\text {fact }}$ & $\begin{array}{l}\text { Erodibility } \\
\text { class [18] }\end{array}$ \\
\hline $\begin{array}{l}\text { EN } 31 \text { US } 7 / 400 \quad 0- \\
14 \mathrm{~cm}\end{array}$ & 14.0 & 22.0 & 4.56 & 4 & 4 & 0.093 & High \\
\hline EN 33192 B/200 0-10 & 29.8 & 12.6 & 3.86 & 4 & 5 & 0.122 & High \\
\hline $\begin{array}{l}\text { EN 51 MB 5/1000 } 0 \text { - } \\
12 \mathrm{~cm}\end{array}$ & 14.8 & 41.2 & 4.11 & 4 & 5 & 0.117 & High \\
\hline $\begin{array}{l}\text { EN 51 NK } 8 \mathrm{~A} / 00 \quad 0- \\
19 \mathrm{~cm}\end{array}$ & 32.0 & 35.4 & 2.87 & 4 & 5 & 0.121 & High \\
\hline US 7A/500 0-18cm & 18.0 & 39.8 & 8.28 & 4 & 5 & 0.118 & High \\
\hline MB 5/200 0-10cm & 24.0 & 38.8 & 6.63 & 4 & 5 & 0.119 & High \\
\hline EN 53, US $/ 6000-15 \mathrm{~cm}$ & 34.6 & 31.4 & 2.54 & 4 & 5 & 0.121 & High \\
\hline $\begin{array}{l}192 \mathrm{~A} / 400 \\
0-12 \mathrm{~cm}\end{array}$ & 14.2 & 10.6 & 2.61 & 4 & 5 & 0.118 & High \\
\hline $\begin{array}{l}\text { 1G 3A/600 } \\
0-10 \mathrm{~cm}\end{array}$ & 9.8 & 22.6 & 4.28 & 4 & 5 & 0.117 & High \\
\hline $\begin{array}{l}\text { EN } 52 \text { MRF } 11 \\
0-10 \mathrm{~cm}\end{array}$ & 25.1 & 12.7 & 4.45 & 3 & 5 & 0.0895 & High \\
\hline MB 3/400 & 14.3 & 23.2 & 1.71 & 4 & 6 & 0.110 & High \\
\hline $\begin{array}{l}\text { MB } 17 \\
0-10 \mathrm{~cm}\end{array}$ & 13.4 & 42 & 4.51 & 4 & 5 & 0.085 & High \\
\hline MB 25 & 11.4 & 12.8 & 3.27 & 4 & 5 & 0.085 & High \\
\hline
\end{tabular}

\subsection{Effect of site characteristics}

\section{Discussion}

Soil series composing the two tributary wetlands varied; however EN 51, covered up to 50\% of the Enyong Creek wetland [12]. Their classes defined the drainage profile of the wetland. The blocky, weak to strong subangular structure of top soil $(0-20 \mathrm{~cm})$ and subsoil composed all the poor, imperfect and duplex soil series of EN 31, EN 33, EN 51 and even EN 52 (Tables 1 and 2). These affected the drainage (hydraulic conductivity) of the soil. Apart from seasonal flooding of the swamps to varying depth of inundation during the rains, standing water was usually observed on the floodplains after the rainy season up to the threshold of the dry season or November (the transition period); while in the deeper depressions, polluted and muddy ponds, may subsist till the end of November [19]. Thus, soil structure affected the hydraulic conductivity, hence drainage in the offrainy period up to the threshold of the dry season. This resulted in the delays on commencement of dry or late season farming on the wetland where the landforms were relatively flat bottom.

\subsubsection{Structural parameter}

The soil structure parameter was high, for its blocky, platty or massive soil, which means that it tended

Table 4. Summary of average erodibility factors, erodibility classes for soil series

In wetland soil of soil creek catchment.

\begin{tabular}{llll}
\hline Soil series & Average $\mathbf{K}_{\text {factor }}$ & Erodibility class & $\begin{array}{l}\mathbf{K}_{\text {sat }} \\
\mathbf{m} / \mathbf{d a y}\end{array}$ \\
\hline EN 51 & 0.119 & high & 6.1 \\
EN 52 & 0.086 & low & 7.3 \\
EN 53 & 0.119 & High & 9.6 \\
EN 31 & 0.093 & High & 3.1 \\
EN 71 & 0.072 & Very low & 8.5 \\
EN 73 & 0.064 & very low & 7.9 \\
EN 75 & 0.575 & Very High & 12.0 \\
EN 81 & 0.575 & Very High & 3.1 \\
\hline
\end{tabular}

$N / B$. See Table 1 for soil type or soil series. The average $K_{\text {factor }}$ shows on the average soil erodibility vary between very low and very high under the varied soil groups. This is higher than the values $0.02-0.06$ (Wischmeieret al, 1971). $K_{\text {sat }}$ - saturated hydraulic conductivity

to be structureless down the profile [12]. As such, the structure was not well defined as granular forms. In that case, it could not promote a network of cracks and large pores that could accommodate infiltrating water that would result in reduced erosion due to decreased runoff [3]. It could be stated that the pondage on the swamps provided a cushion to impactive rain drops on the wetland soil otherwise the level of erosion could have been severe. High $\mathrm{P}_{\text {silt }}$ and $\mathrm{P}_{\text {clay }}$ for some soil series marked the wetland cross-section such as EN 33, 51, 52 in Enyong Creek wetland in Table 3.

The above observations were in contrast with the structural parameter values for Ikpa river catchment (Table 2). The $\mathrm{S}_{\text {struc }}$ was lower than those for Enyong Creek wetland although the values also varied (Table 2). Average value of $S_{\text {struc }}$ for Enyong Creek wetland was 4 (Table 3) while $S_{\text {struc }}$ for Ikpa wetland varied between 2 and 3 with average value of 3 (Table 2). The structure of Ikpa wetland was more developed granular or fine to 
medium granular soils. Hence, the observed high values of clay $\left(\mathrm{P}_{\text {clay }}\right)$ show that clay behaved as the binder to the granular particles such that large pores in the soil accommodated infiltrating water.

\subsubsection{Organic matter parameter, $P_{\text {om }}$}

Soil organic matter (SOM) is a binding agent that agglomerates smaller and individual soil particles into larger aggregates of identifiable shapes [3]. The SOM in Ikpa swamp floor was comparatively higher than $\mathrm{P}_{\mathrm{om}}$ of Enyong Creek wetland except the $0.69 \%$ for IK 10/1000 site in Ikpa swamp. Thus, resistance to erosion water velocity on Ikpa swamp is higher than that on Enyong wetland, because soils that are higher in SOM are more resistant to erosion, hence were precursors to low erodibility[3]. The physical reality is that there was a significant difference at $\mathrm{R}<.05$ in $\mathrm{P}_{\mathrm{om}}$ between Enyong Creek and Ikpa River wetlands.

\subsubsection{Texture class}

Erodibility is governed by four major soil properties, one of which is texture (particle size distribution [3]. Very few soil series in the area were sandy or clayey soils. They were generally loamy soils having not more than $40 \%$ of clay or not more than $55 \%$ of sand, for clayey and sandy soils should have more than $40 \%$ and $55 \%$ clay or sand respectively $[2,20,21]$. Only four cases in Ikpa wetland had soil series with clayey soil; for EN 71 soil series, these were MB 20/1000 (85.6\% clay), IK 11/800 (57.4\% clay) and IK 20/2500 (84.8 clay) and IK 12/400 (62.3\% clay) (Table 2). In Enyong wetland, these were (MB 17/ (42\%) and MB 5/1000 (41.2\% clay) Table 3.Erodibility is low for clay-riched soils. The difference in $\mathrm{P}_{\text {silt }}$ between Enyong Creek and Ikpa river wetland was not significant at $\mathrm{P}=.05$; but significant $(\mathrm{P}=.05)$ was the difference in $\mathrm{P}_{\text {clay }}$ between the two wetland soils.

\subsubsection{Erodibility factor, $\mathrm{K}_{\text {fact }}$}

The computed values of soil erodibilityfactor $\left(\mathrm{K}_{\text {fact }}\right)$ of the wetland soils of Ikpa river and Enyong Creek catchments are given in Tables 2 and 3 respectively. Significant difference $(\mathrm{P}<0.01)$ was observed in $\mathrm{K}_{\text {fact }}$ between EnyongCreek and Ikpa river wetland. The vaues of $\mathrm{K}_{\text {fact }}$ for Ikpa river wetland were single degree lower than those for Enyong Creek wetland, signifying that erodibility or susceptibility to water erosion was lower in Ikpa river wetland than Enyong Creek swamp, other parameters being equal. Using the erodibility factor ranges of $\mathrm{K}$ - factor in equation (1), the erodibility classes for the various K-factors of the soil series were indicated (Tables 2 and 3),varying from very low especially in Ikpa river wetland(Table 2) to low especially in Enyong Creek wetland (Table 3).

The $\mathrm{K}_{\text {fact }}$ varied with soil series. The EN 51 series or poorly drained clays had average of 0.1187 ; the EN 52 or poorly drained sandy and gravelly clays had 0.086; the EN 53 or poorly drained soils with medium over fine textured profiles had 0.1187; the EN 31 or perfectly drained fine textured soils had 0.093; the EN 71 or very poorly drained clays had 0.0719 ; The EN 73 or very poorly drained soils with medium over fine texture profiles had 0.0644 ; EN 75 or poorly to very poorly drained soils with medium over coarse textures had 0.572 while EN 81 or very poorly drained clays with some highly organic subsoil layers had 0.575 . The EN 75 and 81 had sublayer texture-modified duplex soils in Ikpa basin. Their content of organic and or coarse particles influence produced moderate to rapid, rapid or very rapid saturated hydraulic conductivities leading to high flow-through of infiltered water, hence groundwater or sub-surface flow which reduces the chances of surface pondage in micro-topographic depressions and erosive flows on slopes in erosional channels [20].

Thus, the order of erodibility increased with soil series of the upper and lower tributary swamps (i.e. Enyong Creek and Ikpa river wetlands) as follows: EN 81>EN $75>$ EN $51>$ EN $53>$ EN $31>$ EN $52>$ EN 71 $>$ EN 73.The range of soil erodibility on this wetland (being between 0.0073 to 0.575 in all (Table 1), was within the range of 0.02 to 0.69 obtained in [10,20,22]. The average $\mathrm{K}_{\text {fact }}$ and their erodibility class for the soil series are summarized in Table 4 . These were generally low to high for the lower tributary basin wetland but were moderate to high for upper tributary wetland.

The identification of the erodibility classes of these inland agricultural wetlands with respect to their component soils series would benefit our knowledge of the inherent soil properties which have key roles in the prospect and ability of water erosion of their soils where the soil series are mono-dominant or mixed; also, the identified erodibility gave baseline data of the catchments wetlands thereby exposing such soils (with their vulnerable soil series) to be managed under suitable project developments that will reduce the level of soil's erodibility and the prospects of wetland soil erosion.

\subsection{Correlation}

Correlation was investigated between erodibility as intrinsic soil property and other inherent properties of the soil in the two wetlands, which should influence erodibility, namely:granulometry or the soil particles distribution, organic matter and structure. In the wetlands, $\mathrm{P}_{\text {silt }}$ correlated with $\mathrm{K}_{\text {fact }}$ with regression coefficient $\mathrm{r}=$ 0.353 for Enyong Creek wetland soils and $\mathrm{r}=0.508$ for Ikpa river wetland soils indicating equality of effect on $\mathrm{K}$-factor from both wetlands. $\mathrm{P}_{\mathrm{om}}$ and $\mathrm{P}_{\text {clay }}$ had low correlations between them $(\mathrm{r}=0.444$ (Enyong), $\mathrm{r}=0.399$ 
(Ikpa)) indicating marked differences. $\mathrm{P}_{\text {om }}$ and $\mathrm{P}_{\text {clay }}$ were higher in Ikpa than Enyong creek soil series. Attempt to correlate erodibility factors with hydraulic conductivities of the wetland soil series did not yield significant information as the regression coefficient was very low $(\mathrm{r}=0.180)$ and insignificant. Further investigation may be undertaken on this relationship.

\section{Conclusion}

The erodibility factors (or erosion susceptibility) of the Enyong Creek and Ikpa river wetland soils, comprising many different soil series, were investigated using soils granulometry and other inherent properties in the mathematical formulation of Wischmeier et al(1971). Inherent soil particle distribution (percentages of clay, silt, sand), soil organic matter ( $\mathrm{SOM})$, as well as profile permeability class and soil structure were determined and evaluated. Significant difference $(\mathrm{P}<.05)$ existed between the upper and lower tributary wetland soils' properties. Soil erodiblity was observed to be high generally $(0.06-0.121)$ but with values of 0.05 in Ikpa river wetland (lower tributary swamps ) being lower than and significantly different $(\mathrm{P}<.05)$ from those of the uppe tributary swamps $(0.1187)$.

Factors influencing erodibility were also evaluated with silt (\%) and (SOM \%) contributing significantly to lowering K.The study is of benefits to collection of baseline data on soil erodibility of soil drainage type and providing information on erodibility to assist reduce soil susceptibility to erosion under appropriate project development on the wetland.

\section{Acknowledgement}

The author is very thankful to Akwa Ibom State Agricultural Development Project (AKADEP) for all assistance on data availability and permission for field trips with the field staff on their project area.

\section{References}

[1] R. Suresh, Soil and water conservation engineering (New Delhi: Standard Publishers Distributors; 2006)

[2] U.S. Department of Agriculture, Natural Resources Conservation Services, (NRCS),National SoilSurvey handbook, title 430 - VI, 2005. Available at: http://soil.usda.gov/technical/handbook/.

[3] A.T. O'Geen, R. Elkins, D. Lewis, D. Erodibility of agricultural soils, withexamples in Lake and Mendocino countries (Oakland: University of California, Division of Agriculture and Natural Resources, 2006), Publication 8194.

[4] FAO, Natural Resources Management and Environment Department. The land husbandrycomponents and strategy: soil erodibility.(Rome: Natural Resources Management and Environment Department, 2008) Accessed 22 July, 2013. Available at www.fao.org/docrep/t1765e/t1765eof.htm

[5] O. Babalola, Soil properties affecting infiltration, runoff, and erodibility, In V. O. Saqua, E. E. Enabor, G. E.K. Ofomata, K. O. Ologe and L. Oyebande (Eds.),Ecological disasters in Nigeria, (Lagos, Nigeria: Fed. Min. Sci. Tec., 1988).

[6] W. E. Wildman, K. D. Gowans. Some physical environment and how it affects plant growth. (Oakland: Division of Agricultural Sciences, University of California, 1978), Leaflet 2280.

[7] K. Bhattachanya, A. M. Michael, Land drainage principles, method and application (NewDelhi, India: Konark Publishers Pvt. Ltd, 2003).

[8] W. H. Wischmeier, J. V. Mannering, Relation of soil properties to its erodibility. Soil Science Society of America Journal (SSSAJ) 33 (1), 1969, 131-137.

[9] S. J. Goldsman, K. Jackson, Bursztynsky, T. A. Erosion and Sediment Control Handbook, (New York W87- 08688:Mc.Graw Hill Book Co., 1986)

[10] W. H. Wischmeier, C. B. Johnson, B. U. Cross, and contracted sites, Journal of soil and waterconservation 28, $1971,189-192$. ISSN $1941-3300$

[11 Anon, Soil erodibility factor, Available at: epas.pennlgov/mepas/formulations/source_term/5_0/5_32/5.hmtl. Accessed 19 June, 2013.

[12] Akwa Ibom Agricultural Development Project (AKADEP), Northern Akwa Ibom Swamp ResourcesDevelopment Study: Stage 2 Report:Typographical and land use and land capability; Vol.4 (Uyo, Nigeria: AKADEP,1995)

[13] P. R. Day, Particles fractionation and particle size analysis. In: Black et al (eds.), Methods of soil analysis part 1. Agronomy 9, $1965,544-567$.

[14] C. Liu, J. B. Evett, Soil properties testing, measurement and evaluation, 4 edition. (New Jersey: Prentice Hall, 2000)

[15] G. W. Gee, D. Or. Particle size analysis. In methods of soil analysis part 4 physical methods (A. D. Warren (Editor). Soil Sci Soc Am Inc., 2002, 255-295.

[16] A.Walkley and I. A. Black, An examination of a Degtjareff method for determining organic carbon in soil: effect of variations in digestion conditions and of inorganic soil constituents, Soil Sci.6, 1934,251-263.

[17] M. A. Atawoo and J. M. Heerasing, Estimating soil erodibility and erosivity of rainfall patterns in Mauritius, AMAS, 1997, 219223.

[18] L. Lepacha, K. K. Singh, P. M. Ondal and T.K Misra, Sikkim Forest (Gangtok, Thailand: Sikkim State Council of Science \& Technology, 2006).

[19] O. E. Essien, and A. Y. Sangodoyin, Basin-scale temporary distribution of water resources and sensitivity to components contributions in Ikpa catchments of Nigeria, Global Journal of Engineer. \& Technology. 2(2), 2009, 147-153.

[20] D. Flavis - Mortlock, Water erosion, 2008. Accessed 28 June, 2013. Available at: www.soil erosion.net/doc/water_erosion.html

[21] Earth Manual, PART 1,3 $3^{\text {rd }}$ edition (Denver, Colorado:Bureau of Reclamatiom, Department of Interior,1998)

[22] J. K. Mitchel, G. D. Bubenzer, Soil loss estimation, in Kerby, R. P. C. Morgan (Eds): soil Erosion. (London:John Wiley and Sons Ltd.,1980, $17-62)$. 